\title{
Prospective Study of the Pension System in Mexico: AFORES in the Human Rights, Model of Guaranteeism, and Vital Minimum
}

\author{
Enriqueta Mancilla-Rendón, Carmen Lozano \\ Universidad La Salle México \\ Email: maenriqueta.mancilla@ulsa.mx,carmen.lozano@ulsa.mx
}

How to cite this paper: Mancilla-Rendón, E. and Lozano, C. (2018) Prospective Study of the Pension System in Mexico: AFORES in the Human Rights, Model of Guaranteeism, and Vital Minimum. Modern Econo$m y$, 9, 1065-1088.

https://doi.org/10.4236/me.2018.96069

Received: March 22, 2018

Accepted: June 4, 2018

Published: June 7, 2018

Copyright ( $\odot 2018$ by authors and Scientific Research Publishing Inc. This work is licensed under the Creative Commons Attribution International License (CC BY 4.0).

http://creativecommons.org/licenses/by/4.0/

\begin{abstract}
The individual account pension plan will soon recognize those beneficiaries about to receive their pension under this scheme. The 1997 Social Security Law has incorporated strict requirements to the pension plan; therefore, the possibility to obtain a retirement through an individual account is complicated for the employee. The pension will not necessarily guarantee the quality of life given that the retirement funds have been accumulated based on contribution rates and voluntary savings but not on the monthly average of the contribution base wage, which are funds affected by negative yields. The objective of this study is to analyze the AFORES classification SB2 and the performance invested in the SIEFORES to quantify the value of the pension. It applies the hemerographic-legislative technique in the model of the guaranteeism and the principle of the minimum vital in the framework of the human rights, and a quantitative study of time series. It is concluded that individual account system pensions will not guarantee the quality of life of individual account holders.
\end{abstract}

\section{Keywords}

AFORES, Social Security Law 1997, Human Rights, Minimum Pension Guarantee, Vital Minimum Principle

\section{Introduction}

Social security and pension plans have long been an instrument to reach wellbeing horizons during the unproductive years of the population. Internationally, globalization has led to substantial changes and economic crises in the nations. In some cases, it shows imbalance in the distribution of employment, rising in- 
formal economy, plummeting salaries, weak buying power, deficient policies of public finance, and changes in the demographic structure of population, among other variables. All of these promote the generation of reforms or schemes to correct or strengthen tax revenue, acting as mechanisms of fiscal politics as pension funds, the central topic of this study, whose figure is under the control of the State to be invested, mostly in government instruments.

The author ${ }^{1}$ compiled a number of countries that carried out structural reforms to their pension plans [1]. For instance, Chile reformed its scheme into a substitutive model in May 1981, followed by Bolivia (May 1997), Mexico (July 1997), El Salvador (May 1998), Dominican Republic (2003-2006), and Nicaragua (2004). Peru and Colombia implemented a parallel model in June 1993 and April 1994, respectively, while Argentina (July 1994), Uruguay (April 1996), Costa Rica (May 2001), and Ecuador (2004) kept a mixed model. Among the countries that have implemented parametric reforms or no reforms at all are Brazil, Cuba, Guatemala, Haiti, Honduras, Panama, and Venezuela.

These reforms are or have been probably successful in those countries. Meanwhile, France is ranked 19 in human development ${ }^{2}$ and has implemented a parametric reform to its pension scheme [2]. Sweden has a defined benefit pension system, which is supplemented by mandatory individual accounts. It is ranked in the $14^{\text {th }}$ position in terms of human development. The US has a "broad and consolidated benefit plan for retirement, disability, and life [...] and distribution systems and individually capitalized private funds survive complementarily" ${ }^{\text {[1] }}$ and holds the $10^{\text {th }}$ position in terms of human development. Thirty-six years after implementing structural reforms, says Chile is still an obligatory reference to the rest of the world. "Jaime Ruiz-de-Tagle considers the Chilean reform has enabled the fast increase in the national savings rate" ${ }^{\text {[1] }}$ and is ranked 38 in the human development index. These countries belong in the category of very high human development. In the next five years, Mexico will experience the effect of a structural reform; however, the prospects do not seem to be optimistic. Additionally, the country belongs in the category of nations with high human development in position 77, quite far from the countries mentioned before. The aim of this work is to analyze the concept of social security and the figure of pension plan in the 1995 Social Security law and compare them against the old 1973 law to understand whether the pension plan based on individual accounts will ensure the account holders' quality of life within the frame of the model of guaranteeism, human rights, and the principle of vital minimum.

The article is structured in the following way. The first part analyzes the constitutional framework of the pension system to basis on the first law and the evolution of the system of pensions, subsequently makes a review of doctrine of human rights, the model of the guaranteeism, the principle of the vital minimum, and so-

\footnotetext{
${ }^{1}$ It consolidates the models and characteristics of pension reforms in Latin America in 2004.

${ }^{2}$ The index of human development incorporates indices of health, education, and income.

${ }^{3}$ Gascón, p. 127.

${ }^{4}$ Gascón, p. 129.
} 
cial security (AFORES). It continues with a review financial-theoretical investment instrument and the institutions to manage the resources (SIEFORES). After it explains the methodology that was developed in the study to shed the analysis of the results (SB2), and finally makes a discussion and provisional assessment in which one identifies the contribution and limitation of this article.

\section{Pension Plan Constitutional Framework}

Mexico is a country that maintains the precepts of social security since the enactment of the 1917 Constitution. These principles were reinforced [3] by the passing of the Civilian Pension $\mathrm{Law}^{5}$, which included "the protection of health, loans, and old-age, disability, and survivor pensions"6, and further strengthened by the promulgation of the Social Security Law in 1943 [4]. The creation of the Mexican Social Security Institute (Instituto Mexicano del Seguro Social, IMSS) institutionalized social security given that it became a mechanism to provide social security to employees working in both the private sector and autonomous entities of the federal government. Once the law was passed, social security "became a matter of State policy"7 [5]. Social security consists of the rights to health, medical assistance, livelihood protection, and welfare services needed for individual and collective wellbeing, besides granting an old age pension guaranteed by the State.

Four decades ago, the defined benefit pension plan (1973 Social Security Law $[6])^{8}$ was established. It provides a lifelong pension plan at the end of the productive years of the beneficiary that is inherent to peace and financial security in old age. The defined benefit scheme includes legal compliance requirements as the obligation of employees to have at least 500 weeks of contribution before the IMSS and be aged $65^{9}$. The basis of the pension plan is created by the monthly average of the last five years of contribution base wage reported to IMSS. This pension system still provides people who registered at IMSS before June 30, 1997, with the chance to obtain a defined benefit and lifelong pension plan for old age determined by the five-year average of their contribution base wage. The situation of those beneficiaries registered from July $1^{\text {st }}, 1997$, is entirely different due to the reforms implemented in disability, life, severance, and survivor insurance of the pension plan.

Along with the validity of the 1995 Social Security Law ${ }^{10}$, the government created a scheme in which the employees have an individual account of defined

\footnotetext{
${ }^{5}$ According to Treasury Secretary Pany (1926, La política hacendaria y la revolución) the beneficiaries of this law were those responsible for a civil servant position who were not military. Recipients were also teachers and those providing services as craftsmen, operators, or help, with the exception of deputies and senators (Article 3). The higher command of the administrative and judiciary powers and any other public official legally immovable were not subject to this law (Article 4).

${ }^{6}$ Centro de Investigación Económica Presupuestaria (2017) p. 3.

${ }^{7}$ Farfán, p. 186.

${ }^{8}$ Third section (Articles 137 to 142 ) and fourth section (Articles 143-148), Diario Oficial de la Federación, (12/03/1973). Abrogated 1973-1994.

${ }^{9}$ Article 138. Right to enjoyment of benefits from old age insurance.

${ }^{10} 1995$ Social Security Law went into effect throughout Mexico on July $1^{\text {st }}, 1997$.
} 
contribution [7] in the finance system administered by a Retirement Funds Administrator (Administradora de Fondos para el Retiro, AFORE). The account integrates the employee and the employer's social security contributions as well as those from the State ${ }^{11}$ in addition to the yields generated [3]. Also, together with voluntary savings [1], the beneficiary could receive an old age pension after turning 65, providing the existence of 1250 weeks of contribution to IMSS.

In this scenario, it is apparently unclear how an individual account system, as opposed to a defined benefit scheme, can guarantee the employees' lifestyle according to their contribution base wage when the defined benefit scheme provides an old age pension guaranteed by the State that is granted according to the registered contribution base wage. On the contrary, the individual accounts plan only considers the amount of contributions and, if applicable, the employees' voluntary savings, which is probably bound to a savings system of an insurance company.

Besides the contribution base wage, the weeks of contribution represent a factor that influences the granting of an old age pension, there is a substantial difference between the 500 weeks of contribution required by the 1973 Social Security Law and the 1250 weeks of contribution in the 1995 Social Security Law, which are variable according to employment. If the workers have a stable job for 25 years, they coerce to obtain the weeks of contribution established by the new law. Considering the current scenario of the pension system, The Organization for Economic Co-operation and Development [8] has stated that the beneficiary "who was registered a month before the introduction of the new pension system will be granted higher pensionary benefits than those that an individual who was registered a month after will receive" ${ }^{\prime 2}$.

The key question in this analysis is whether the contributions by employees, employer, and the State, which fund the individual account of a beneficiary administered by AFOREs, are enough to grant an old age pension according to the contribution base wage of the last five years ensuring the quality of life at the moment of retirement in the frame of the model of guaranteeism.

Are the worker's contributions and voluntary savings and the employer and State's contributions managed by AFOREs during the 1250 weeks of contribution by the beneficiary's individual account invested in adequate financial instruments so that they provide positive yields to guarantee, together with the contributions, a decent old age pension in agreement with the contribution base wage and according to the principle of vital minimum?

\section{Human Rights, Model of Guaranteeism, and Vital Minimum}

According to Karl Loewenstein [9], human rights must be based on "fundamental socioeconomic rights"13, a notion which broadens their implementation

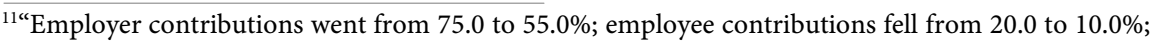
while State contributions rose from 5.0 to $35.0 \%$ of the total contribution". Centro de Investigación Económica Presupuestaria (2017) p. 7.

${ }^{12}$ OECD (2016) p. 4.

${ }^{13} \operatorname{Vargas}(2017)$ p. 21. 
range when playing an unavoidable role in people's dignity. From Charles Taylor's reflection, [10] "essentially considers rights as mechanisms to protect the individual's autonomy over the State and society"14. In contrast, Ferrajoli points out that human rights are no longer "an internal limit of the sovereign power but have emerged as a limit supported by international law"15. The Fourth Collegiate Court in Administrative Matters of the First Circuit dogmatically explains the obligation all authorities have, within their competences, "to promote, respect, protect, and guarantee human rights according to the principles of universality, interdependence, indivisibility, and progressiveness" ${ }^{16}$. In this spirit, human rights related to health, social security, culture, sports, housing, diet and water, and sanitation, among others, are invulnerable because they are inherent to the conditions of quality of life for human development. Therefore, the State's obligation "to progressively achieve the complete effectiveness of the rights derived from economic, social, educational, scientific, and cultural standards" ${ }^{17}$ is legitimized, leading to the State's obligation, according to its degree of development, to guarantee economic, social, and cultural rights [11 $]^{18}$.

In this sense, [12] is right on legal universalism where human rights lie, limit the meaning of life and truth, and connote the equality of the person against natural rights. Then, in old age, as an involution process, it must be joined by human rights, incorporated to a lifelong pension. We must consider then whether at this stage of life human rights, and specifically social security, are no

\footnotetext{
${ }^{14}$ Prado (2007) p. 62.

${ }^{15}$ Prado (2007) p. 64.

${ }^{16}$ Political Constitution of the United Mexican States (1917) Article 1, third paragraph: “All authorities, in their areas of competence, are obliged to promote, respect, protect, and guarantee human rights, in accordance with the principles of universality, interdependence, indivisibility, and progressiveness. As a consequence, the State must prevent, investigate, penalize, and rectify violations to human rights, according to the law." ${ }^{17}$ SEMANARIO JUDICIAL DE LA FEDERACION. Tribunales Colegiados de Circuito. Decima Época, Libro XIX (2013), p. 2254. "PRINCIPLES OF UNIVERSALITY, INTERDEPENDENCE, INDIVISIBILITY AND PROGRESSIVENESS OF HUMAN RIGHTS. WHAT THEY CONSIST OF. The third paragraph of Article 1 of the Political Constitution of the United Mexican States points out that, among other questions, all authorities, in their areas of competence, are obliged to promote, respect, protect, and guarantee human rights, in accordance with the principles of universality, interdependence, indivisibility, and progressiveness, which consist of: 1) universality: they are inherent to all and concern the international community in its entirety; in this way, they are inviolable, which does not mean they are absolute but protected because human dignity cannot be infringed since it is reasonable to think they are adapted to circumstances; therefore, by virtue of this flexibility, they are universal, given that their nature allows them to be with the person when adapting to contingencies, and to that regard, the Interamerican Court of Human Rights (Case "Mapiripan massacre vs Colombia) has stated that human rights treaties are living instruments whose evolving interpretation accompanies evolution in time and current living conditions and is in accordance with general rules of interpretation established in Article 29 of the American Convention on Human Rights and the Vienna Convention on the Law of Treaties; then, such rights, within their limits, are inalterable; that is, their core is essential and intangible and for that reason, the fundamental rule considers that not even in state of emergency are they "suspended"; in any case, they will always agree with the principles of international humanitarian law; 2) interdependence and indivisibility: that are related to one another, meaning they cannot be separated nor are they more important than others; they must be interpreted and taken as a whole, not as isolated elements. All human rights and fundamental freedoms are indivisible and interdependent; equal attention and urgent consideration must be given to the application, promotion, and protection of civil, political, economic, social, and cultural rights; that is, complement, potentiate or reciprocally reinforce them; and 3) progressiveness: it constitutes the compromise of States to adopt providences, both internally and through international cooperation, especially when it is economic and technical, to achieve the progressive and plain effectivity of the rights derived from economic, social, educational, scientific, and cultural standards; this principle cannot be understood if governments do not have the immediate obligation to achieve the entire realization of these rights; on the contrary, they are understood in the possibility of moving forward gradually and constantly towards the most complete realization, within their material resources, and thus this principle demands that, as the development of a State improves, the level of compromise to guarantee economic, social, and cultural rights must also improve."

${ }^{18}$ Previous analyses of fundamental rights in the history of Mexican constitutional texts clearly refer to the protection of the Constitution and human rights.
} 
longer effective. The $2^{\text {nd }}$ CXXVII/2015 Unsettled Case Law of the Second Courtroom clarifies, based on the principle of progressiveness, the demand that "all authorities of the Mexican State, within their competences, increase the degree of protection in the promotion, respect, protection, and guarantee of human rights and also, by virtue of its non-regressivity expression, prevents them from implementing measures that, without any constitutional justification, reduce the level of protection to human rights of those who are subject to the legal system of the Mexican State"19.

On the other hand, Ferrajoli refers to guaranteeism and in it conceptualizes the model in three different aspects. From the rule of Law, he considers [13] the model as a legal theory that establishes the State with the recognition of rights. In this context, the State is in charge of the protection and guaranty of the citizens' natural (vital) rights. The author states that "individuals and their rights, needs, and interests, in that they are previous and represent a priority, are natural", consequently, the State "is only legitimized as long as it aims to protect those rights and individual assets" ${ }^{20}$. "In summary, in its substantial dimension, it is a condition of validity ensured by the observation of fundamental rights"21, social right that must satisfy or maintain freedom rights.

One of the most significant contributions to social rights is described ${ }^{22}$ who says [14] these rights are fulfilled when a "state organization" imposes them; in addition, they "need social support". These social rights have three objectives: respect, protection, and compliance. The author explains that respect means the State "must refrain from doing anything that violates the integrity of individuals, [...] or risks their freedom or rights". The State has the moral duty to protect rights as well as "implementing measures to prevent other agents from violating social rights" and the obligation of complying since it must take action so that persons "have the opportunity to enjoy their rights when they cannot do it by themselves" 23 .

${ }^{19}$ SEMANARIO JUDICIAL DE LA FEDERACION Tesis aislada 2a. CXXVII/2015 (10a.) Segunda Sala Decima Época. Libro 24, Tomo II (2015): pp. 1298. "PRINCIPLE OF PROGRESSIVENESS OF HUMAN RIGHTS. THEIR NATURE AND FUNCTION IN THE MEXICAN STATE. The principle of progressiveness that rules in matter of human rights involves both graduality and progress. Graduality refers to the fact that effectiveness of human rights is not generally achieved immediately but carries a whole process that implies defining short-, mid-, and long-term goals. For its part, progress implies the enjoyment of rights must always be improved. In that sense, the principle of progressiveness of human rights is related not only with the prohibition of regressivity of enjoying fundamental rights but also with the positive obligation of promoting them progressively and gradually given that, as the Permanent Constituent pointed out, the Mexican State has the constitutional mandate to make all changes and transformations needed in the economic, social, political, and cultural structure of the country to guarantee that all people can enjoy their human rights. Therefore, the alluded principle demands that all authorities of the Mexican State, within their competences, increase the degree of protection in the promotion, respect, protection, and guaranty of human rights and also prevents them, by virtue of its expression of non-regressivity, from adopting measures that, without any constitutional justification, reduce the level of protection of human rights of those who are subject to the legal system of the Mexican State."

${ }^{20}$ Gascón (2001) p. 198.

${ }^{21}$ Gascón (2001) p. 201.

${ }^{22}$ Carbonell (2004) p. 780.

${ }^{23}$ Carbonell (2004) p. 786. 
To channel the concept of lifelong pension within the frame of human rights and model of guaranteeism, specifically social security, we begin by analyzing the definition of wage. Exhibits [15] the importance of wages by stating there is a vital minimum wage that "ensures the vital needs of the employee [...] seeking the employee's improvement and not his or her stagnation"24. He also considers the concept should be extensive to those persons about to be granted a pension according to the 1995 Social Security law. This law [16] defines wage $e^{25}$ as contribution base wage, consisting of the daily wage integrated with benefits in kind and cash. Once the contribution base is integrated, the amount of employee-employer contributions is calculated, along with the fees for the pension system where employer, State, and employee converge. How the opinion [17] considers that "there is no definition of integrated or contribution base wage"26; however, this wage emerges when benefits in kind are added to the nominal wage received by the employee together with the surplus of the benefits obtained in cash per contractual agreement with the employer ${ }^{27}$. The Political Constitution of the United Mexican States indicates that the State protects human dignity [18], guarantees human rights ${ }^{28}$, and is required to promote economic and employment growth as well as a fair income and wealth distribution. To allow for the individual's dignity $^{29}$, the State must guarantee that the employees' salary is enough to maintain the content of the right to individual's dignity and vital minimum income. On this regard [19], the $1^{\text {st }}$ XCVIII/2007 Unsettled Case Law of the First Courtroom (May $\left.1^{\text {st }}, 2007\right)$ considered:

"The constitutional right to the vital minimum is completely valid from the systematic interpretation of the fundamental rights established in the General Constitution and, particularly, in articles 1, 3, 4, 6, 13, 25, 27, 31 section IV, and 123. A democratic State based on the rule of law is supposed to demand that all individuals be under the adequate conditions to develop an autonomous life plan to aid them in their active participation in the democratic life. In this way, the enjoyment of the vital minimum is a presupposition without which the core of our constitutional order becomes meaningless. Then, the intersection between

\footnotetext{
${ }^{24}$ González (1968) p. 199.

${ }^{25}$ Articles 82,83 , and 84 of the Labor Law describe that a salary is the retribution that an employer must pay the employee for work and can be fixed by time or job units, commission, fixed price, or any other way, in addition to other benefits derived from the work relationship, including the employee's participation in the profits of the companies. Salary is composed of cash payments by daily quote, gratifications, perceptions, housing, bonuses, commissions, benefits in kind, and any other amount or benefit that the employee receives for work.

${ }^{26}$ Morales (2008) p. 135.

${ }^{27}$ Article 27. Contribution base wage is composed of cash payments for daily quote, gratifications, perceptions, diet, housing, bonuses, commissions, benefits in kind, and any other amount or benefit delivered to the employee for work", excluding "additional contributions the employer agrees to grant in favor of employees as contributions to retirement insurance, old age severance, and old age.

${ }^{28}$ Article 1. In the United Mexican States all persons will enjoy human rights acknowledged in this Constitution and international treaties of which the Mexican State is part, as well as guarantees for their protection.

${ }^{29}$ Article 25. Leadership of national development that allows for the complete exercise of freedom and dignity of individuals, groups, and social classes whose security is protected by this Constitution.
} 
State power and the fundamental rights and freedom structure consists of the determination of a minimum, dignified, and autonomous livelihood that is constitutionally protected. This parameter creates the content of the law of vital minimum, which in turn, agrees with competences, basic conditions, and social benefits necessary for the person to lead a life free of fear and the burden of misery. Then, the law of the vital minimum includes all unavoidable positive or negative measures to prevent the people from having their inherent value as human beings unconstitutionally reduced only because they lack the material conditions that allow for a dignified livelihood. Therefore, this law seeks to guarantee that people-core of the legal system-do not become an instrument for other ends, objectives, purposes, goods, or interests, regardless their importance or value."

\section{The Doctrinal Structure of Social Security}

Social security ${ }^{30}$ guarantees Mexicans the right to a pension plan at old age. From this perspective, the State as guarantor of human rights is required to respect, protect, and comply with this right. Social security is under the control of entities or public offices, whether local or federal, and decentralized bodies ${ }^{31}$. The Social Insurance ${ }^{32}$ is the instrument that IMSS uses, according to [5], as responsible for the organization and administration. Social Insurance consists of two contribution schemes ${ }^{33}$, one mandatory ${ }^{34}$ and one voluntary ${ }^{35}$. The mandatory scheme is in charge of dealing with retirement and old age and old age severance. In this way [20], "Social Security provides its beneficiaries with a wide range of benefits in kind and cash"36. Benefits in kind include medical and pharmaceutical assistance, as well as prosthetics, orthopedics, rehabilitation, mortuary services, and daycare. Cash benefits are provided in money, based on the salary the employee is registered, also known as contribution base wage; both disability and pension payments are included in this benefit.

Insurance of old age severance is a category in which the beneficiary does not have paid work from age 60 and demands 1250 weeks of contribution to IMSS [21]. This type of severance forces the Institute to grant a pension plan and benefits in kind (medical assistance, family allowances, and welfare aid). Those beneficiaries who have not completed the weeks of contribution but have reached

${ }^{30}$ Article 2. It guarantees the right to health. 1995 Social Security Law.

${ }^{31}$ Article 3. Social Security is under the control of public entities.

${ }^{32}$ Article 4 . Social Insurance is the basic instrument of social security.

${ }^{33}$ Article 6. Schemes of Social security.

${ }^{34}$ Article 11. Compulsory System of the Social Security Law includes insurance for 1. Sickness and maternity, 2. Daycare and social welfare, 3. Disability and life, 4. Retirement, old age severance and old age, and 5. Occupational risks.

${ }^{35}$ Article 13. People can be voluntary subjects of insurance under the compulsory system. 1) employees in family industries and independent workers as professionals, small traders, artisans, and self-employed; 2) Domestic workers; 3) Ejido members, co-proprietors, settlers, and smallholders; 4) Employers of natural persons with insured workers under service; and 5) Workers at the service of public administrations of the Federation, states, and municipalities excluded or not included in other laws or decrees as subjects of social security.

${ }^{36}$ IDC (2016) p. 1. 
the desired age collect the resources they have accumulated ${ }^{37}$. The author [22] addressed old age pension plans by saying they provide the beneficiaries aged 65 who have contributed with 1250 weeks with an individual account to enjoy an old age pension. To this end, beneficiaries can obtain an annuity from an insurance company or maintain the individual account balance in an AFORE, and then make programmed withdrawals ${ }^{38}$.

Employers are bound to report the amount of employee-employer contributions to the Institute, along with the State contribution to create the insurance for retirement, old age severance and old age. The fees are deposited in the individual account of each employee. As for retirement, the employer is in charge of covering an amount equal to $2 \%$ of the employee's contribution base wage. In the categories of old age severance and old age [3], the employer contributes with $3.150 \%$ and the employee with $1.125 \%$, while the State contribution amounts for $7.143 \%$ of the total employer fees. The law also establishes the Federal Government must provide a contribution for each day of contribution wage; that is, the government provides an amount of money as social contribution for those employees who earn 15 times the current minimum wage in Mexico City. The money is sent to the beneficiary's individual account according to the contribution base wage: $\$ 3.87$ for up to 1 minimum wage, $\$ 3.70$ for up to 4 minimum wages, $\$ 3.54$ for up to 7 minimum wages, $\$ 3.38$ for up to 10 minimum wages, and $\$ 3.22$ for up to 15 minimum wages ${ }^{39}$.

\section{SIEFORES and Investment Instruments}

This tripartite contribution is deposited bimonthly in the beneficiaries' individual accounts and those banking institutions through an AFORE, which is in charge of managing and investing savings in pension funds (Sociedades de Inversion Especializadas de Fondos para el Retiro, SIEFOREs) ${ }^{40}$ to obtain the maximum benefits for the insured person at a moderate risk. They [23] explain the characteristics of the types of investments of AFOREs after analyzing the newsletters the National Commission for the Retirement Savings System (Comision Nacional del Sistema de Ahorro para el Retiro, CONSAR) published on July 9, 2007, October 12, 2012, and June 4, 2013 (Table 1). CONSAR classifies employees' individual accounts by AFORE Generation according to age and calls them Basic SIEFORE (SIEFORE Basica, SB). Workers aged 60 or older are SB1; those aged between 46 and 59 are SB2; employees aged between 37 and 45 are SB3; and those aged 36 and younger are SB4 [24].

Based on the investment scheme, SIEFOREs analyze the type of instruments to be used with the savings from AFOREs, which are invested in Government

\footnotetext{
${ }^{37}$ Article 154 Old age severance when the insured loses paid work.

${ }^{38}$ Article 157. Requisites to make use of the individual account.

${ }^{39}$ Article 168. Fees and contributions.

${ }^{40}$ National Commission for the Retirement Savings System (CONSAR) approves the following SIEFOREs to invest the resources of the insured individual accounts: Profuturo, SURA, Banamex, Coppel, Pension ISSSTE, MetLife, Azteca, Principal, XXI Banorte, Inbursa, Invercap.
} 
Table 1. SIEFOREs investment instrument.

\begin{tabular}{|c|c|c|c|c|}
\hline Type of SIEFORE & $\mathrm{SB} 1^{\mathrm{a}}$ & $\mathrm{SB} 2^{\mathrm{b}}$ & $\mathrm{SB}^{\mathrm{c}}$ & $\mathrm{SB} 4^{\mathrm{d} \#}$ \\
\hline $\begin{array}{l}\text { 1) At least } 51 \% \text { in debt instruments whose return is equal to or } \\
\text { higher than that of UDIs or INPC }\end{array}$ & $\mathrm{X}^{*}$ & & & \\
\hline $\begin{array}{l}\text { 2) Up to } 100 \% \text { in debt instruments guaranteed by the Federal } \\
\text { Government or issued by Bank of Mexico }\end{array}$ & $\mathrm{X}$ & $\mathrm{X}$ & $\mathrm{X}$ & $\mathrm{X}$ \\
\hline 3) Up to $100 \%$ of debt instruments with the highest credit scores & $\mathrm{X}$ & & & \\
\hline 4) Up to $20 \%$ in foreign debt securities & $\mathrm{X}$ & $\mathrm{X}$ & $\mathrm{X}$ & $\mathrm{X}$ \\
\hline 5) Up to $10 \%$ in securitized instruments & $\mathrm{X}$ & $\mathrm{X}$ & $\mathrm{X}$ & $\mathrm{X}$ \\
\hline 6) Up to $5 \%$ in equity instruments & $\mathrm{X}$ & $\mathrm{X}$ & $\mathrm{X}$ & $\mathrm{X}$ \\
\hline 7) Up to $5 \%$ in structured instruments & $\mathrm{X}$ & $\mathrm{X}$ & $\mathrm{X}$ & $\mathrm{X}$ \\
\hline
\end{tabular}

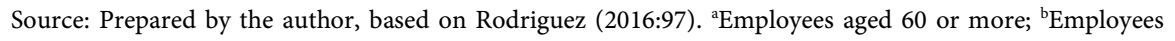
aged 46-59; ${ }^{\mathrm{C}}$ Employees aged 37-45; ${ }^{\mathrm{d} E m p l o y e e s ~ a g e d ~} 36$ or younger. Notes: ${ }^{*}$ Including CKDs (except for SB1), FIBRAs and Certificates whose payment source are real assets. " $S$ Since November 12, 2012, SB5 SIEFORE resources are incorporated to SB4 SIEFOREs.

Debt, Foreign Debt, National Debt ${ }^{41}$, Structured, Infrastructure and Real Estate Trust (Fideicomisos de Infraestructura y Bienes Raíces, FIBRAs), International Equity Instruments, and National Equity Instruments.

Government [25] bonds are issued by the federal government and currently are Development Bonds (Bonos de Desarrollo, BONDES D), instruments the government issues through the Secretary of Finance and Public Credit (Secretaría de Hacienda y Crédito Público, SHCP). Bonds are auctioned and the participants present their bids ${ }^{42}$. Development Bonds (Bonos de Desarrollo, BONOS) were issued for the first time in the year 2000 with maturities of 3, 5, 10, 20, and 30 years. They pay interests every six months at a fixed interest rate. Development Bonds denominated in Investment Units (Bono de Desarrollo en Unidades de Inversion, UDIBONO) were issued in 1996 and are instruments that protect the investor from inflation. [25] UDIBONOs are issued with maturities of 3,10, and 30 years and pay interests every six months at a fixed interest rate, according to Bank of Mexico [26]. Federation Treasury Certificates (Certificado de la Tesoreria de la Federacion, CETE) are the oldest debt instrument. Issued for the first time in January, 1978, CETEs are fundamental to the development of the money market in Mexico. These certificates do not pay interests and are settled at nominal value. Their highest maturity is one year, although they are issued with maturities of up to two years, the general instrument having a maturity of 28 days [27]. The Institute for Bank Savings Protection (Instituto para la Proteccion al Ahorro Bancario, IPAB) is the federal entity responsible for

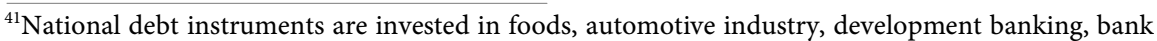
instruments, beverages, cement, shopping malls, consumption, short-term debt, productive State companies, states, Europesos, industrial clusters, infrastructure, paper, financial services, steelmaking, telecommunications in transport, and housing.

${ }^{42}$ Banco de México newsletter 5/2012 directed to credit institutions, stock markets, investment companies specialized in retirement funds and Rural Financial, related to auctions to place government and IPAB securities.
} 
managing the insurance of bank deposits of small and medium savers. States that IPAB is the government institution in charge of issuing Savings Protection Bonds (Bono de Proteccion al Ahorro, BPA) while the Bank of Mexico is the financial agent [28]. Their maturities are 3, 5, and 7 years and pay interests at periods similar to those of CETEs. The bond that pays monthly interests is known as BPAG28; the one paying quarterly interests is BPAG91; and the instrument paying interests every six months is BPA182.

National debt instruments are issued by companies or government by public or private offer [29]. A public offer is done via mass media as newspapers or newsletters of the Mexican Stock Exchange (Bolsa Mexicana de Valores, BMV). A private offer is directed to a person or group of investors and remains unknown to the rest of the market. The author considers that these debt instruments are structured instruments, trust securities aimed for investment or financing of domestic activities or projects of one or more trading companies whose shares are traded on the stock market. Rodriguez points out that equity investments are carried out by public or private companies in capital stock. These shares are traded in other national and international stock markets so that investors can decide to trade their securities in these investments.

They [30] consider that FIBRAs are securities issued by the trust dedicated to acquisition or construction of real estate within the country and income from lease of real estate.

CONSAR has defined the concepts described in Investment in Merchandise through SIEFOREs [31]. These are financial operations derived from or underlying commodities as gold, silver, or platinum listed by Bank of Mexico as "being considered expendable property different from shares, price or equity indices, rates, national and foreign currencies, investment units, loans, and credits" ${ }^{33}$.

The operation policies of SIEFOREs involve a System of Commission, which consists in charging commissions for the administration of individual accounts belonging to the employees registered. The amount of the commission is an annual percentage on the value of the resources accumulated in the employee's individual account. It is created through a daily supply in the valuation of share values of SIEFOREs where the employee's savings are. SIEFOREs are also bound to report to the employees the risks Investment funds are exposed to. The risk of investment is associated to a financial risk [23], which is in turn related to the possibility of losses in the investment portfolio of the SIEFORE caused by liquidity, market, or credit risk, including legal and operational risk ${ }^{44}$. When there are losses derived from the non-compliance with the Investment System, CONSAR foresees [31] "the redrawing of the portfolio of Investment Funds, in ${ }^{43}$ SIEFORE XXI (2016) p. 11.

${ }^{44}$ Rodriguez (2016) p. 177. In previous pages, Rodriguez deals with the history of risks and returns of investment in Mexico and stresses the statement by DERAKSHANI et al. (2000) that "reforms to the social security system in Mexico, which allow for the placement of retirement funds in money market instruments, and reforms to the Investment Companies Law, which allow for fund operators to define their own private objectives and that promote foreign participation in fund commercialization, have resulted in a promising future for the investment fund market in that country." 
which we describe the cases when the Administrator operating the Investment Fund is forced to cover the losses charged to the special reserve of the Administrator, If the reserve is insufficient", the administrator will cover for the losses with its share capital ${ }^{45}$.

\section{Study Methodology}

The aim of this work is to analyze the contributions and yields that the AFORE-SIEFORE investment instruments have generated for individual SB2 accounts. We also seek to estimate the approximate monthly amount the individual account holder will receive once complying with the legal requirements of being aged 65 and having 1250 weeks of contribution at IMSS. This is an exploratory, descriptive, correlational, and cross-sectional study [32] carried out using legal procedures of critic and documentary hermeneutic desk research [33] It intends to explain that the accumulated balance of an individual SB2 account, together with employer and State contributions and yields generated, according to the 4-month account statements of AFORE-SIEFORE, is sufficient to obtain a vital minimum pension plan in agreement with the contribution base wage that guarantees the beneficiary's quality of life.

Following the approach suggested [34], the first stage of the study is a review of the contextual, theoretical, and hermeneutic information of the current pension system in Mexico and the one that will take effect, according to the existing Social Security Law of July $1^{\text {st }}, 1997$. Afterwards, we review the legal-hermeneutic literature on Social Security as human right and the legal and theoretical basis of the model of guaranteeism and the principle of vital minimum, according to the legal frame of the system for retirement savings and the 1995 Social Security Law. The rates of employer-employee contributions are known to identify the percentage of employer contributions to employees' individual accounts and those of the Federal Government. The AFOREs are identified as are SIEFOREs working within the System for Retirement Savings and the financial instruments in which SIEFOREs invest retirement funds. In addition, we review the concept of financial expense due to fund administration. The second stage of the study identifies the holder of the individual account and deals with historical data of the AFORE to carry out a quantitative study. We make a prospective and statistical analysis of a time series regarding the calculation of resources the account holder will receive at the moment of retirement, based on the accumulated balance of the account statements released by the AFORE. The balance is composed of the joint contributions of the employee, the employer, and the State as well as the yield from investments by the SIEFORE.

A stochastic process is a set of random variables $\left\{Y_{t}\right\}_{t \in T}$ defined on the same space of probability. An observation of the values of the random variables is known as completion of the stochastic process. A time series is the completion of a stochastic process in a discrete time, where the elements of $T$ are ordered and

${ }^{45}$ SIEFORE XXI (2016) p. 66. 
correspond to equidistant moments in time; for example $T=\mathbb{Z}$, (set of integers). In other words [28], a time series describes the random evolution of a variable in time [35]. The analysis of time series is a quantitative method used to detect patterns of change or permanence in the data collected across time. After the analysis of time series, we make projections of the patterns found to obtain an estimate for the future regardless the reason why it will occur.

In a stochastic process there are certain characteristics that describe its behavior: means, variances, and covariances. These characteristics vary across time given that they are functions in a time variable.

The mean in a stochastic process $\left\{Y_{t}\right\}_{t \in T}$ is a function $t$ which provides expectations of variables $Y_{t}$ for every moment $t$

$$
\mu_{t}=E\left(Y_{t}\right) .
$$

The function of variances of a stochastic process $\left\{Y_{t}\right\}_{t \in T}$ is a function of $t$ which provides variances of the $Y_{t}$

$$
\sigma_{t}^{2}=\operatorname{Var}\left(Y_{t}\right), t \in I .
$$

The function of autocovariances of a stochastic process $\left\{Y_{t}\right\}_{t \in T}$ is a function that describes the covariances between the variables of the process in every pair of moments

$$
\operatorname{Cov}\left(Y_{t_{1}}, Y_{t_{2}}\right)=E\left[\left(Y_{t_{1}}-\mu_{t_{1}}\right)\left(Y_{t_{2}}-\mu_{t_{2}}\right)\right], t_{1}, t_{2} \in T .
$$

White noise. Denoted by $\varepsilon_{t}$, White noise is a simple case of stochastic processes in which independent values are equally distributed across time, with the following characteristics

- $E\left(\varepsilon_{t}\right)=0$

- $\operatorname{Var}\left(\varepsilon_{t}\right)=\sigma_{t}^{2}$

- $\operatorname{Cov}\left(\varepsilon_{t}, \varepsilon_{s}\right)=0$ si $t \neq s$.

White noise can be interpreted as a succession of unrelated values, oscillating around zero within a constant margin.

Among methods of time series, there are simple smoothing methods, which are based on the supposition that there exist visible patterns in the time series plot that can be extrapolated to future. That is, the future value of a variable $Y$ in time $t+1$ depends on the value of the time series in the current period $t$ and the previous period $t-1, \ldots$; that is:

$$
Y_{t+1}=f\left(Y_{t}, Y_{t-1}, Y_{t-2}, Y_{t-3}, \cdots\right) .
$$

Some methods of time series are based on the assumption that the data are stationary, while the mean, variance, and autocorrelation do not change in time and there usually are no stationarity patterns. Still, in practices there are these trend- and season-like patterns; therefore, it is necessary to have models that take them into account. Among the patterns that are usually considered, three stand out: a trend component that indicates increase or decrease; a season component that indicates repetitive patterns in the short-term, depending on the 
frequency of the series; and a cyclical component which is harder to spot but is equally important, although it occurs after an extended period of time. Writing the components of a time series is known as decomposition of a time series. To carry out this decomposition, exponential smoothing methods are a widely used tool which provides a good prediction. The simplest exponential smoothing method is Simple Exponential Smoothing (SES). It is generally used in non-stationary series and supposes the series has the model

$$
Y_{t}=\mu+\varepsilon_{t},
$$

and seeks to estimate the value $\mu$ in the following way: a parameter $\alpha \in[0,1]$ is chosen; it indicates the weight given to the real and current datum. The new smoothed datum $s_{t}$ will depend on the real datum $Y_{t}$ and the smoothed datum $s_{t-1}$, which depends on datum $Y_{t-1}$ and smoothed datum $s_{t-2}$, etc. Then, the smoothed datum can be expressed as

$$
s_{t}=\alpha Y_{t}+(1-\alpha) Y_{t-1}+(1-\alpha)^{2} Y_{t-2}+\cdots,
$$

where $s_{t}$ is the smoothed value in time $t, Y_{t}$ is the value of the series in period $t$ and $\alpha$ is the smoothing parameter. Holt's method is a more general case. It starts from a SES but under the assumption of having both trend and season-like components. Later, the component "damping" is added. For this case, the following model is assumed:

$$
Y_{t}=l+t * b+\varepsilon_{t} .
$$

We apply two SES with two parameters $\alpha$ and $\beta$, one is used to estimate the component of level $l$ and the other to estimate the trend component $b$. From this, predictions can be made. For the purposes of this work, we must consider a damping factor $\phi$ that allows for the decrease in the effect of the trend to increase time, so that the trend becomes constant in the future. The factor $\phi$ acts in such a way that, instead of having the prediction $t+h$ to $t+h+1$ increase $b_{t}$, it only increases $\phi^{h} b_{t}$. Therefore, the prediction for time $t+h$ will be

$$
s_{t+h}=l_{t}+\left(1+\phi+\cdots+\phi^{h-1}\right) * b_{t},
$$

where $l_{t}$ and $b_{t}$ are the values estimated by the method. While the exponential smoothing methods allow for predictions in the short term, Holt's method is a more elaborated tool that provides predictions in mid and long terms [36].

The next step is to determine whether Holt's model is appropriate to explain the behavior of the accumulated balance in the account statements issued by the AFORE. That is, we must verify that the model proposed is closer to the series observed; if so, the residuals behave like white noise. Residuals are defined as

$$
e_{t}=Y_{t}-s_{t} \text {. }
$$

The series $e_{t}$ is analyzed to detect whether it exhibits an autocorrelated dynamic or white noise. If the residuals behave like white noise, then they should not show serial dependence (autocorrelation). Then, in the first stage we analyze the plot of the autocorrelation function (correlogram) and evaluate the null hy- 
pothesis; that is, we consider that the term of disturbance corresponding to an observation is independent from the one corresponding to any other observation. The Ljung-Box test allows us to determine whether the series $e_{t}$ is white noise [37].

To provide predictions and reports of results, we use $R$ open-source software (The $R$ Project for Statistical Computing), which is a set consisting of libraries and a programming language frequently used for the analysis of time series [38]. The final result is presented in two different ways: punctual prediction and confidence interval. The latter is a range of values calculated so that there is some certainty, an $80 \%$ or $95 \%$ of confidence that the real value of the predicted variable is within such range.

1) Study sample: The Unit of analysis consists of a holder of an XXI Banorte AFORE account classified in group SB2: persons aged between 46 and 59 who are subject to the 1995 Social Security Law and will soon apply for an old age pension plan of the individual account system. The contribution base wage is $\$ 48,640.60$ and the fixed integrated daily wage is $\$ 1621.33 \mathrm{MXP}$.

We analyze the investment instruments and permitted asset operations of an SB2 beneficiary [39]. The data were recovered from the accumulated 4-month account statements going back five years. These documents were issued by XXI Banorte AFORE, which classifies weighted investment instruments in five categories:

a) Up to $100 \%$ in debt securities guaranteed by the Federal Government and issued by Bank of Mexico.

b) Up to $20 \%$ in foreign debt securities.

c) Up to $15 \%$ in securitized instruments.

d) Up to $25 \%$ in equity instruments.

e) Up to $15 \%$ in structured instruments.

2) Variables

This is how we understand the variables depending on employer, State, and employee contributions, yields, and voluntary savings.

Independent variables as interest rate, term, and nominal value of a) Government equity instruments: BONDEs D, BONOs, BPAs, CETEs, UDIBONOS, PIC-FARAC, CBIC, REPORTO, and UMS; b) Corporate fixed-rate bonds; c) Global fixed income instruments; d) National fixed income instruments; e) International equity instruments; and f) Structured instruments and FIBRAS. The instruments of investment are taken as independent variables because they are the instruments in which the basic SIEFORE 2 (SB2) invests the resources, of which a financial yield is obtained, according to the applied interest rate.

\section{Analysis Results}

We examined the final balances in the account statements of 15 4-month periods corresponding to the last five years of contribution of the SB2 XXI Banorte AFORE, from May 2012 to April 2017. According to Table 2, the final balance is 
composed of employer, employee, and State contributions as well as yields generated by the accumulated resource invested in SIEFOREs. Indeed, both contributions and yields are affected by the amount of commissions; that is, the charges the AFORE makes for the administration of the resources.

The series with historical 4-month data of XXI Banorte AFORE is shown in Figure 1.

Table 2. SB2 classification. BANORTE XXI AFORE.

\begin{tabular}{|c|c|c|c|c|c|c|c|c|}
\hline Year & \multicolumn{2}{|c|}{ Period } & Previous balance & Contributions & Withdrawals & Income & Commissions & Final balance \\
\hline 2012 & 01-may & 31-ago & $159,005.91$ & $189,966.94$ & $-178,446.34$ & 9542.12 & 726.14 & $179,342.49$ \\
\hline 2012 & 01-sep & 31-dic & $174,342.49$ & 9475.21 & -6.94 & 6596.23 & 827.14 & $194,579.85$ \\
\hline 2013 & 01-ene & 30-abr & $194,579.85$ & 7709.92 & - & $15,342.19$ & 791.98 & $216,839.98$ \\
\hline 2013 & 01-may & 31-ago & $216,839.98$ & $11,608.69$ & - & $-17,087.34$ & 781.10 & $210,579.63$ \\
\hline 2013 & 01-sep & 31-dic & $210,579.63$ & $11,651.99$ & - & 8883.79 & 809.69 & $230,305.72$ \\
\hline 2014 & 01-ene & 30-abr & $230,305.72$ & $10,291.10$ & - & 4471.43 & 823.94 & $244,244.31$ \\
\hline 2014 & 01-may & 31-ago & $244,244.31$ & $11,548.92$ & - & $13,831.04$ & 907.18 & $268,717.09$ \\
\hline 2014 & $01-$ sep & $31-\mathrm{dic}$ & $268,717.09$ & 8141.58 & - & 2124.49 & 961.75 & $278,021.41$ \\
\hline 2015 & 01-ene & $30-a b r$ & $278,021.41$ & 8994.30 & - & 5250.63 & 1241.29 & $291,024.95$ \\
\hline 2015 & 01-may & 31-ago & $291,024.95$ & $11,596.90$ & - & 1161.73 & 1041.94 & $300,418.18$ \\
\hline 2015 & 01-sep & 31-dic & $300,418.18$ & 9449.55 & - & 2181.76 & 1042.03 & $311,008.46$ \\
\hline 2016 & 01-ene & $30-a b r$ & $311,008.46$ & $12,126.91$ & - & 7887.09 & 1064.29 & $329,958.17$ \\
\hline 2016 & 01-may & 31-ago & $329,958.17$ & $11,922.26$ & - & $10,121.32$ & 1123.03 & $350,878.72$ \\
\hline 2016 & 01-sep & 31-dic & $350,878.72$ & $10,373.42$ & - & -8531.32 & 1178.90 & $351,541.92$ \\
\hline 2017 & 01 -ene & 30 -abr & $351,541.92$ & $11,609.47$ & - & $13,867.23$ & 1208.06 & $375,810.56$ \\
\hline
\end{tabular}

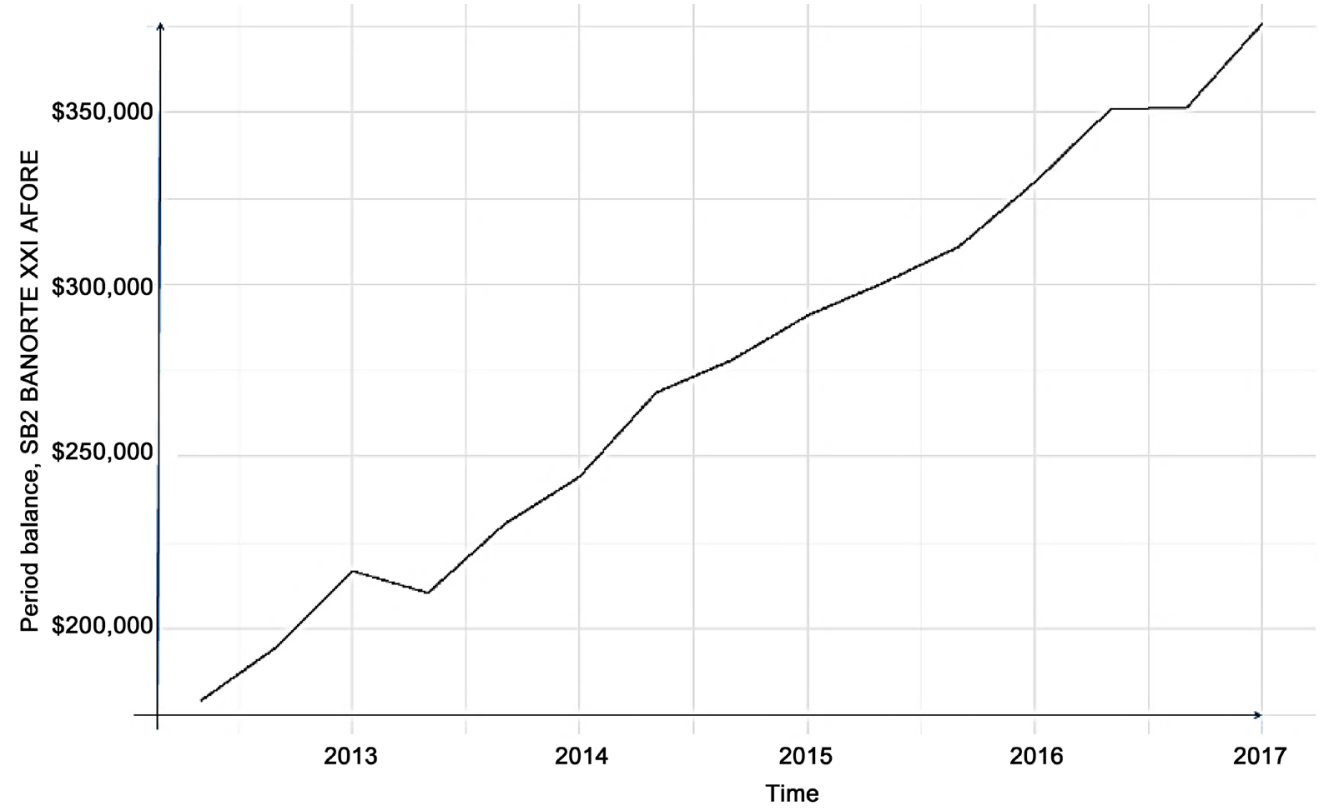

Figure 1. Historical behavior of the Time Series corresponding to the four-month period balance, SB2 BANORTE XXI AFORE. 
We must highlight that in the second 4-month period in 2013, the final balance was integrated with negative yields of $\$ 17,087.34 \mathrm{MX}$, which means the savings fund was affected by a financial loss, reducing savings from $\$ 216,839.98$ to $\$ 210,579.63$ MX. The pension fund decreased in $2.90 \%$, effectively showing that the yield of this period $(\$ 11,608.69)$ did not exist given the loss of investment shown in Figure 1. Nevertheless, even if the graph shows a trend of benefit, there is a negative yield again in the second period of 2016. The stagnation of the accumulated balance is evident in the next balance, showing the yield and linear growth of the accumulated resource by the first period of 2017. We were unable to identify the type of instrument in which XXI Banorte SIEFORE invested the financial resource since we discovered that the fund denied the information to the account holder after it was requested. Therefore, the analysis of independent variables globally influences this study.

We propose a Holt's model to calculate the resources the account holder will receive at the moment of retirement, based on the accumulated balance in the account statements issued by the AFORE integrating the employee, employer, and State contributions as well as the yield generated by investments of SIEFORE.

We analyzed the residuals, as shown in Figure 2. The residual plot shows a purely random behavior, so the model captures the most relevant characteristics observed in the data; that is, the accumulated balance of the contributions by the employee, the employer, and the State, together with the yields generated minus the financial expense. This proved the chosen model provides a mathematical object that describes the behavior of the data shown in Table 2; from this, a prediction can be made. When examining the autocorrelation plots (Figure 3), we obtained a first analysis in which value $p$ does not reject the null hypothesis (white noise).

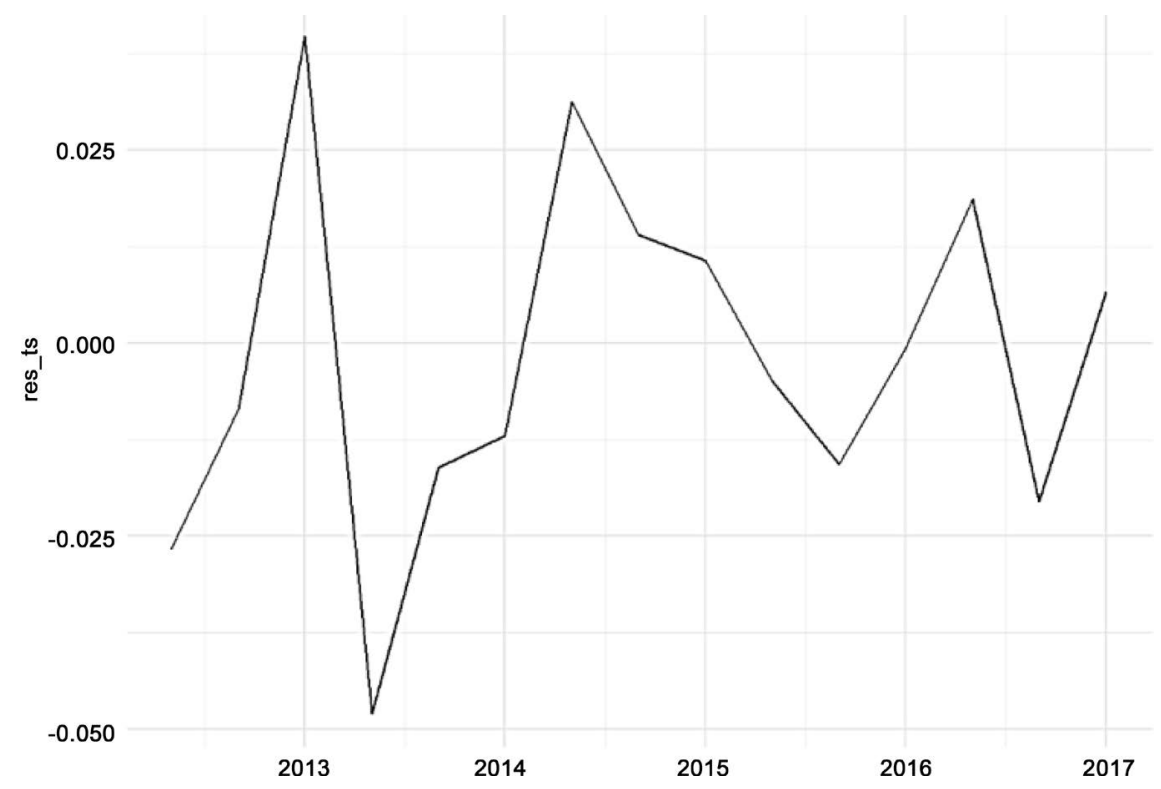

Figure 2. Residuals of the time series corresponding to BANORTE XXI AFORE. 


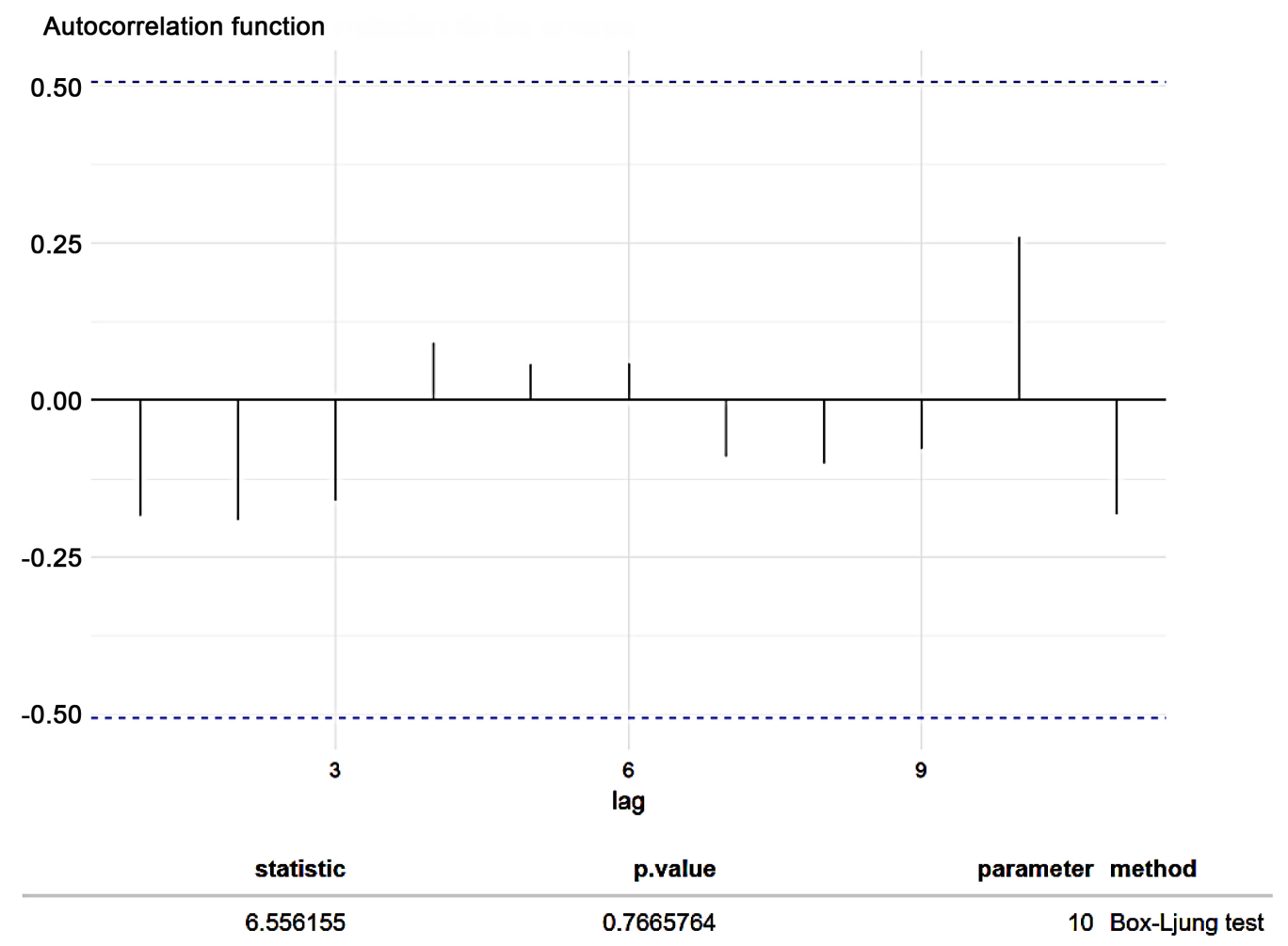

Figure 3. Autocorrelation function (correlogram) of the BANORTE XXI AFORE time series. The blue horizontal lines represent confidence bands.

It evidently is white noise, since the values of the autocorrelation function do not go over the confidence bands (Bartlett's bands). This indicates it is white noise because the autocorrelation shown is significantly zero, which is confirmed by Ljung-Box test.

After identifying the residuals behave as white noise, we adjusted the data using a Holt's model dampened with exponential trend. The model is given as shown below.

Following Holt's method described in the methodology, we made an adjustment (Figure 4). We used $R$ project software to adjust the parameters $\alpha, \beta$, and $\phi$ of Holt's method.

In Figure 5, presented below, we observe the degree of adjustment corresponding to the predicted values (final balances integrated with employee and employer contributions together with yields) with the model and the values observed for the final balances in Table 3 with a confidence level between 80 and $95 \%$.

The prediction of employee, employer, and State contributions and yields in the period of time analyzed is given in Table 3.

By year 2032, the retirement savings accumulated in XXI Banorte AFORE are $\$ 927,857.15 \mathrm{MX}$. Confidence intervals of 80 and $95 \%$ of the prediction are $(874,751.69 ; 923,992.10)$ and $(862,407.62 ; 937,606.06)$, respectively. Then, there is $80 \%$ confidence that the retirement savings accumulated in the AFORE will be between $\$ 874,751$ and $\$ 923,992$ MX. There is a $95 \%$ confidence that the 


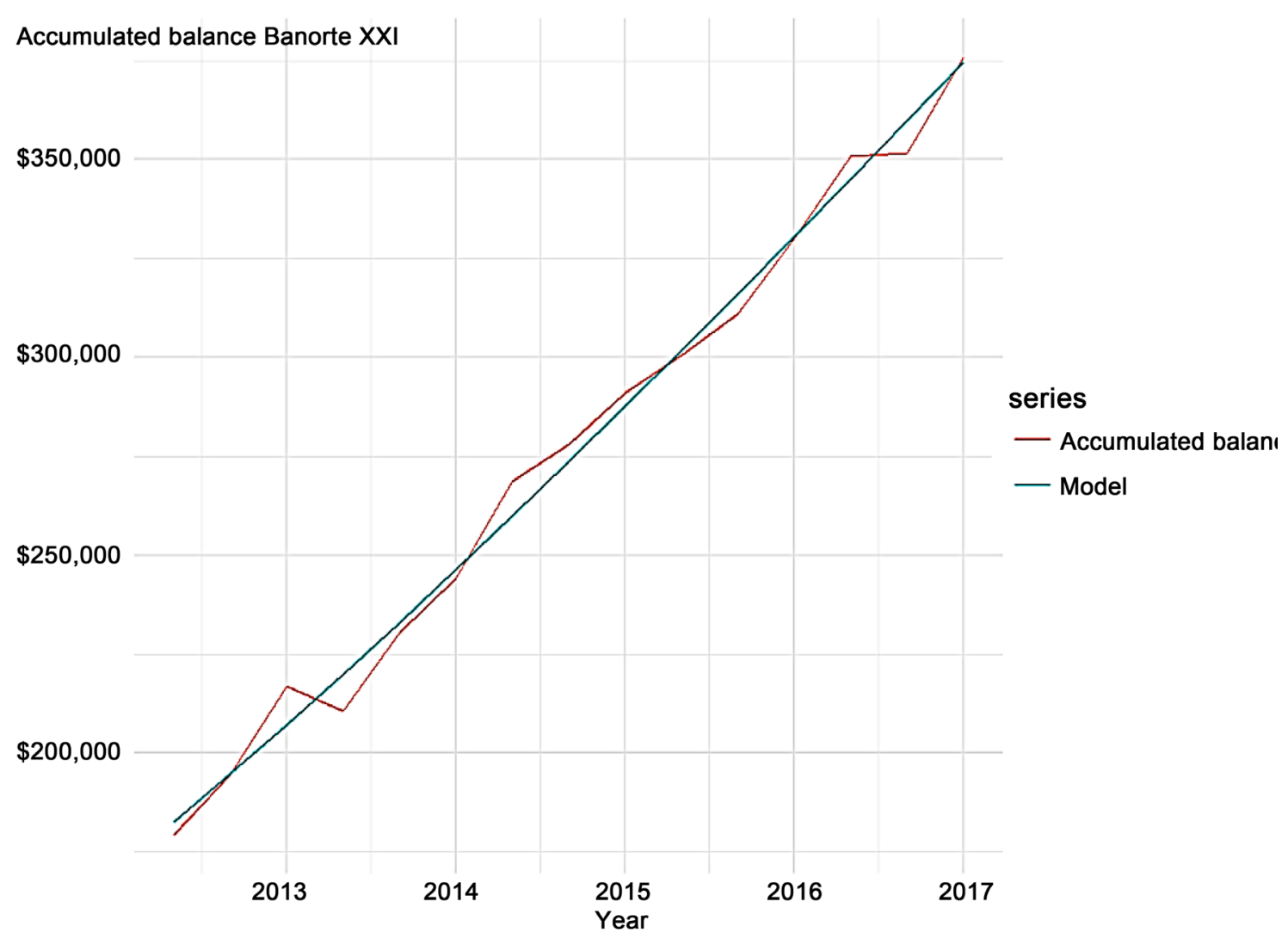

Figure 4. Holt's model adjusted to the following parameters: $\alpha=0.0003 ; \beta=0.0001$; and $\phi=0.9645$.

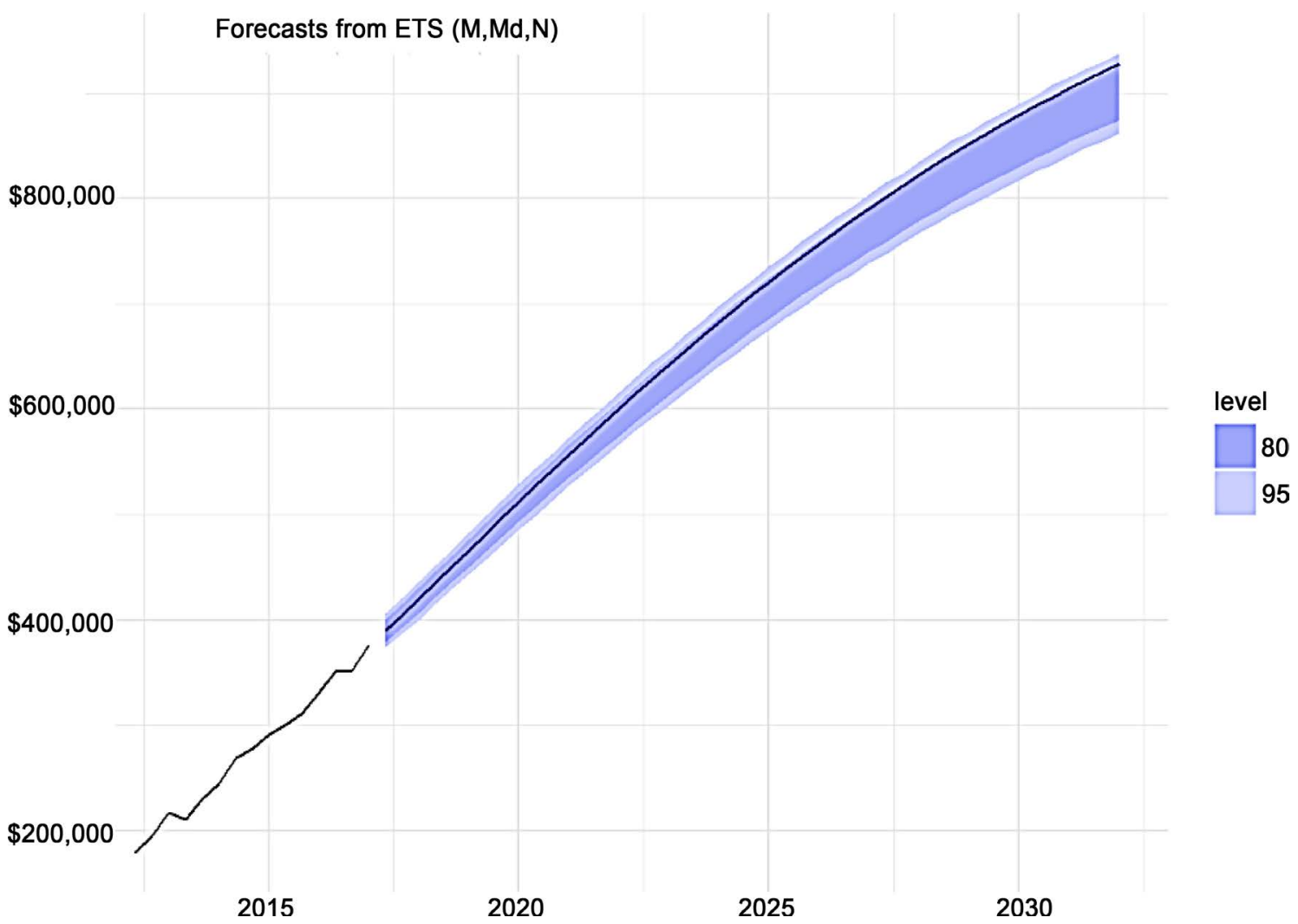

Figure 5. Prediction obtained from the proposed model. 
Table 3. Prediction results.

\begin{tabular}{|c|c|c|c|c|c|c|c|c|c|c|c|}
\hline Year & $\begin{array}{c}\text { Point } \\
\text { Forecast }\end{array}$ & Lo 80 & Hi 80 & Lo 95 & Hi 95 & Year & $\begin{array}{c}\text { Point } \\
\text { Forecast }\end{array}$ & Lo 80 & Hi 80 & Lo 95 & Hi 95 \\
\hline 2025 & $720,739.88$ & $685,821.61$ & $724,924.48$ & $675,487.18$ & $735,390.24$ & 2025 & $720,739.88$ & $685,821.61$ & $724,924.48$ & $675,487.18$ & $735,390.24$ \\
\hline 2025 & $732,993.95$ & $696,667.85$ & $736,274.10$ & $686,322.79$ & $746,667.85$ & 2025 & $732,993.95$ & $696,667.85$ & $736,274.10$ & $686,322.79$ & $746,667.85$ \\
\hline 2026 & $745,010.36$ & $708,147.74$ & $748,825.57$ & $697,154.24$ & $759,859.50$ & 2026 & $745,010.36$ & $708,147.74$ & $748,825.57$ & $697,154.24$ & $759,859.50$ \\
\hline 2026 & $756,786.78$ & $718,146.57$ & $760,373.74$ & $706,661.88$ & $770,977.04$ & 2026 & $756,786.78$ & $718,146.57$ & $760,373.74$ & $706,661.88$ & $770,977.04$ \\
\hline 2026 & $768,321.46$ & $728,678.66$ & $770,825.53$ & $718,077.01$ & $781,604.25$ & 2026 & $768,321.46$ & $728,678.66$ & $770,825.53$ & $718,077.01$ & $781,604.25$ \\
\hline 2027 & $779,613.20$ & $739,406.73$ & $782,117.81$ & $728,375.82$ & $793,620.37$ & 2027 & $779,613.20$ & $739,406.73$ & $782,117.81$ & $728,375.82$ & $793,620.37$ \\
\hline 2027 & $790,661.28$ & $749,668.78$ & $793,366.65$ & $738,250.51$ & $803,871.98$ & 2027 & $790,661.28$ & $749,668.78$ & $793,366.65$ & $738,250.51$ & $803,871.98$ \\
\hline 2027 & $801,465.46$ & $759,067.96$ & $803,512.02$ & $748,316.43$ & $814,972.80$ & 2027 & $801,465.46$ & $759,067.96$ & $803,512.02$ & $748,316.43$ & $814,972.80$ \\
\hline 2028 & $812,025.94$ & $769,119.38$ & $812,291.26$ & $756,947.46$ & $823,887.94$ & 2028 & $812,025.94$ & $769,119.38$ & $812,291.26$ & $756,947.46$ & $823,887.94$ \\
\hline 2028 & $822,343.34$ & $778,072.12$ & $823,488.35$ & $766,617.47$ & $835,676.36$ & 2028 & $822,343.34$ & $778,072.12$ & $823,488.35$ & $766,617.47$ & $835,676.36$ \\
\hline 2028 & $832,418.65$ & $788,485.50$ & $832,404.14$ & $775,543.56$ & $845,487.29$ & 2028 & $832,418.65$ & $788,485.50$ & $832,404.14$ & $775,543.56$ & $845,487.29$ \\
\hline 2029 & $842,253.22$ & $796,591.26$ & $842,860.42$ & $785,068.05$ & $855,099.79$ & 2029 & $842,253.22$ & $796,591.26$ & $842,860.42$ & $785,068.05$ & $855,099.79$ \\
\hline 2029 & $851,848.73$ & $805,056.74$ & $850,917.88$ & $792,930.94$ & $862,606.57$ & 2029 & $851,848.73$ & $805,056.74$ & $850,917.88$ & $792,930.94$ & $862,606.57$ \\
\hline 2029 & $861,207.16$ & $813,954.24$ & $860,635.98$ & $801,231.34$ & $872,962.47$ & 2029 & $861,207.16$ & $813,954.24$ & $860,635.98$ & $801,231.34$ & $872,962.47$ \\
\hline 2030 & $870,330.76$ & $822,540.63$ & $869,840.76$ & $810,543.58$ & $883,174.04$ & 2030 & $870,330.76$ & $822,540.63$ & $869,840.76$ & $810,543.58$ & $883,174.04$ \\
\hline 2030 & $879,222.03$ & $831,012.51$ & $877,694.65$ & $818,098.92$ & $890,671.96$ & 2030 & $879,222.03$ & $831,012.51$ & $877,694.65$ & $818,098.92$ & $890,671.96$ \\
\hline 2030 & $887,883.71$ & $837,873.24$ & $886,268.02$ & $825,133.80$ & $898,937.73$ & 2030 & $887,883.71$ & $837,873.24$ & $886,268.02$ & $825,133.80$ & $898,937.73$ \\
\hline 2031 & $896,318.74$ & $846,325.98$ & $894,066.89$ & $833,734.12$ & $906,177.17$ & 2031 & $896,318.74$ & $846,325.98$ & $894,066.89$ & $833,734.12$ & $906,177.17$ \\
\hline 2031 & $904,530.24$ & $852,619.21$ & $902,268.65$ & $840,037.64$ & $916,212.08$ & 2031 & $904,530.24$ & $852,619.21$ & $902,268.65$ & $840,037.64$ & $916,212.08$ \\
\hline 2031 & $912,521.49$ & $859,588.92$ & $909,939.43$ & $845,441.95$ & $923,079.94$ & 2031 & $912,521.49$ & $859,588.92$ & $909,939.43$ & $845,441.95$ & $923,079.94$ \\
\hline 2032 & $920,295.94$ & $867,761.18$ & $917,969.52$ & $854,219.40$ & $931,043.48$ & 2032 & $920,295.94$ & $867,761.18$ & $917,969.52$ & $854,219.40$ & $931,043.48$ \\
\hline 2032 & $927,857.15$ & $874,751.69$ & $923,992.10$ & $862,407.62$ & $937,606.06$ & 2032 & $927,857.15$ & $874,751.69$ & $923,992.10$ & $862,407.62$ & $937,606.06$ \\
\hline
\end{tabular}

Source: Prepared by the author. Dates obtained from the proposed model.

accumulated retirement savings in the same AFORE will be between $\$ 862,407$ and $\$ 937,606$ MX. By this year, the holder of the SB2 account is expected to receive a pension in monthly instalments of $\$ 4062.87 \mathrm{MX}$.

\section{Discussion and Provisional Evaluation}

Finding the data of the SB2 account evidences the unsatisfactory behavior of yields because the SIEFORE had probably invested, up to the date of the study, in high-risk investment instruments, so that they could not provide positive yields to improve savings. It is worth mentioning that the account holder asked the SIEFORE which investment instruments, terms, and rates had been used to invest the savings; however, the information was denied, violating the holder's 
right "as long as it is done in a written way, peacefully and respectfully", according to the Constitution Article 8 [40]. In this sense, savings in AFOREs are vulnerable to economic behaviors, which makes the holder susceptible to variables out of his or her control. In addition, the account holder did not approve the way in which the savings were invested using financial instruments.

The Social Security Law in effect from July $1^{\text {st }}, 1997$ institutes strict requirements to the pension system, so the possibility to obtain a retirement plan by individual account is complicated. In fifteen years, the holder of the SB2 individual account will fulfill the first requisite to be candidate to a lifelong pension: 1250 weeks of contribution, in case of having a stable source of work. The first limitation the individual account pension system has is the small probability of making contributions to the Social Security, since there is a high uncertainty around employment in Mexico, to a certain degree; the State must promote economic development (Article 25). The current pension system does not provide employment that adjusts to a social security system because employers refuse to hire employees under legal, long, and lasting conditions (Article 123). In fact, the employment reform carried out in 2012 inhibits the growth of formal employment and promotes temporary, hourly, or reduced-schedule employment.

If an employee contributed with 1250 weeks, then he or she would obtain the minimum guaranteed pension. If the employee had chosen a voluntary-savings scheme, then he or she would be able to obtain a higher pension, which is complicatedly given that salaries are increasingly low. In most of the cases, salaries are not enough to provide for the basic needs. Therefore, the culture of saving is not promoted. In addition, those beneficiaries who manage to fulfill the legal requisites are not given a guarantee of life quality because their retirement funds have been accumulated based on contribution rates and voluntary saving and not on contribution base wage, as the old scheme had. Hence, we understand why the human development index in Mexico is the lowest when compared against the other countries.

The individual accounts pension system might only satisfy those who manage to save using their own resources. It has been proven that the amount of employee, employer, and State contributions together with yields accumulated at the date of granting is insufficient. In consequence, the monthly instalment of the pension is insufficient as well. Then, the monthly instalment of an SB2 account holder would receive as old age pension is the minimum guaranteed equivalent to a monthly wage, which currently is $\$ 2433.21$ MX. By the year 2032, the holder will receive \$4062.87 MX monthly. For the SB2 AFORE account holder whose contribution base wage is $\$ 48,640.60 \mathrm{MX}$ in comparison with other wages, the monthly instalment to get would probably be insufficient to guarantee a decent life, including education, personal security, income and wealth, social, recreational and sport activities, health, environmental quality, housing, and civil compromises (Articles 1, 3, 4, 6, 13, 25, and 27). The holder of an SB2 AFORE individual account is not only financing a rigorous pension system but he or she is also doing so with the current pension system through the manda- 
tory contributions to public expense (Article 31, Section IV). In summary, the prospective study of the current pension system, based on individual accounts, clearly violates human rights and social security. The State, guarantor of fundamental rights, must promote, respect, protect, and guarantee human rights according to the principles of universality, interdependence, indivisibility, and progressiveness since it is co-responsible for the development of individuals. The combination of State power and fundamental rights and freedoms determine a decent livelihood and the right to the vital minimum, a principle protected not only by the Constitution but also by international standards.

The main contribution of the study is that the new generations will not enjoy a pension to originate by a pension system supported by a government via public expenditure. The pension that a citizen will enjoy at the time of the old age is the one that obtains of its own savings; of an income that already tax payment, and that these savings will and must be sufficient to live dignity. Another way, it will be generating a new class of poverty. The limitation of the study exhorts to analyze other cases with financial treatment beneficiary with individual account AFORE SB3 or individual account AFORE SB4, and another SIEFORE that offers attractive yields rates and lower commissions. This motivates to extend the stages and to supplement the study.

\section{Acknowledgements}

The paper presented is one of the results of the research under the Project entitled "Salaries and the vital minimum" of the research group Study of fiscal, accounting and auditing standards of the Universidad La Salle México.

\section{References}

[1] Vásquez Colmenares, P. (2006) Seguridad Social en materia de pensiones en Espinosa. En: Alberto, Ed., Sistema de pensiones en México. Perspectivas financieras y posibles soluciones, Editorial Instituto Mexicano de Ejecutivos en Finanzas, México, 111-164.

[2] Centro de Inve Programa de las Naciones Unidas para el Desarrollo (2016) Informe sobre Desarrollo Humano 2016. PNUD, Estados Unidos.

[3] Stigación Económica Presupuestaria (2017) Pensiones en México. Cien años de desigualdad. CIEP, México.

[4] The Social Security Law in 1943, Diario Oficial de la Federación (19/01/1943) México.

[5] Farfán, G. (2009) Los orígenes del Seguro Social en México: Un enfoque neoinstitucional histórico. Editorial UNAM, México.

[6] Law Social Security 1973.

[7] Solís, F. (2006) Planes de pensiones personales e institucionales en Espinosa. En: Alberto, Ed., Sistema de pensiones en México. Perspectivas financieras y posibles soluciones, Editorial Instituto Mexicano de Ejecutivos en Finanzas, México, 45-77.

[8] Organización para la Cooperación y el Desarrollo Económico (2016) Estudio de la OCDE sobre los sistemas de pensiones. OCDE, México.

[9] Vargas, J. (2017) El Plan de Guadalupe y el Congreso Constituyente. En: Vargas, J., 
Ramírez, J. and Soler, R., Eds., Estudios sobre la Constitución Mexicana en el Cincuentenario de la Facultad de Derecho, Editorial De La Salle, México, 11-22.

[10] Prado, M. (2007) Limitación de los Derechos Humanos. Algunas Consideraciones Teóricas. Revista Chilena de Derecho, 34, 61-90. https://doi.org/10.4067/S0718-34372007000100005

[11] González, M. and Castañeda, M. (2015) La evolución histórica de los derechos humanos en México. Comisión Nacional de Derechos Humanos, México.

[12] Burgoa, C. (2017) La tributación a 100 años de la constitución. Artículo 31 fracción IV Constitucional. En: Vargas, J., Ramírez, J. and Soler, R., Eds., Estudios sobre la Constitución Mexicana en el Cincuentenario de la Facultad de Derecho, Editorial De La Salle, México, 101-119.

[13] Gascón, M. (2001) La teoría general del garantismo a propósito de la obra de L. Ferrajoli “Derecho y Razón”. Jurídica, Anuario del departamento de derecho de Universidad Iberoamericana, No. 31, 195-213.

[14] Carbonell, M. (2004) Los derechos fundamentales en México. Comisión Nacional de Derechos Humanos, UNAM, México.

[15] González, F. (1968) Ética Social. Editorial Porrúa, México.

[16] Ley Federal del trabajo, Diario Oficial de la Federación (01/04/1970) (12/06/2015, última reforma). Ciudad de México, México.

[17] Morales, M. (2008) El salario y la previsión social entre el derecho social y el fiscal. http://www.redalyc.org/articulo.oa?id=429640262007

[18] Carbonell, M. (2007) Los derechos fundamentales y la acción de inconstitucionalidad. En: Astudillo, C. and Carbonell, M., Eds., Las comisiones de derechos humanos y las acciones de inconstitucionalidad, Comisión Nacional de Derechos Humanos, UNAM, México, 75-91.

[19] Semanario Judicial de la Federación (2007) Primera Sala. Novena Época. Derecho al mínimo vital en el orden constitucional mexicano. Tesis Aislada 1a. XCVIII/2007, Tomo XXV (2007), 793. Ciudad de México, México.

[20] IDC (2016) Mi pensión ante el IMSS. 50 preguntas y respuesta para conocer cómo, cuándo y quienes pueden obtener este beneficio económico, IDC Asesor jurídico y fiscal, 30 Octubre, 1-73.

[21] Ley del Seguro Social, Diario Oficial de la Federación (21/12/1995) (12/11/2015, última reforma). Ciudad de México, México.

[22] Orendaín, I. (2006) Efectos fiscales y legales de las pensiones, en Sistema de pensiones en México. En: Espinosa, A., Ed., Perspectivas financieras y posibles soluciones, Editorial Instituto Mexicano de Ejecutivos en Finanzas, México, 81-109.

[23] Rodríguez, A. and Dorantes, P. (2016) La reciente reforma financiera en México: Transformaciones y perspectivas. http://oai.redalyc.org/articulo.oa?id=363544478004

[24] Ley del Sistema de Ahorro para el Retiro, Diario Oficial de la Federación, (23/05/1996) (10/01/2014 última reforma). Ciudad de México, México.

[25] Banco de México (2012) Descripción Técnica de los Bonos de Desarrollo del Gobierno Federal BONDES D. Secretaría de Hacienda y Crédito Público, México.

[26] Acosta, M. and Álvarez, C. (2014) Tipos de instrumentos y su colocación en Mercado de Valores gubernamentales en México.

http://www.banxico.org.mx/elib/mercado-valores-gub/OEBPS/Text/ii.html

[27] Guzmán, M. (2006) Un modelo de predicción del tipo de cambio spot para la 
economía Mexicana. http://www.redalyc.org/articulo.oa?id=41304707

[28] Levy, N. (2005) La efectividad de las operaciones de mercado abierto en países emergentes. México en los noventa. http://www.redalyc.org/articulo.oa?id=363542887004

[29] Rodríguez, A. (2004) Riesgos y rendimientos de los fondos de inversión en México. http://4www.redalyc.org/articulo.oa?id=41304108

[30] Serrano-García, I., Rodríguez-García, M., Méndez-Sáenz, A. and Treviño-Saldívar, E. (2016) Análisis financiero de las fibras en México. Vinculatégica, 1, 489-499.

[31] SIEFORE XXI Banorte Consolida (2016) Prospecto de Información al público inversionista Sociedad de Inversión Especializada de Fondos para el Retiro (SIEFORE Básica 2). SIEFORE XXI Banorte Consolida, México.

[32] Hernández, R., Fernández-Collado, C. and Baptista, P. (2006) Metodología de la Investigación. McGraw-Hill, México.

[33] Álvarez, J. (2003) Cómo hacer investigación cualitativa, fundamentos y metodología. Editorial Paidós Educador, México.

[34] Vieytes, R. (2009) Campos de aplicación y decisiones de diseño en la investigación cualitativa. En: Merlino, A., Ed., Investigacion Cualitativa en Ciencias Sociales, Cengaje Learning, Argentina, 43-84.

[35] Pérez, F. (2007) Introducción a las series de tiempo. Métodos paramétricos. Universidad De Medellín, Colombia.

[36] Berenson, L. and Levine, D. (1996) Estadística básica en administración: Conceptos y aplicaciones. Pearson Educación, USA.

[37] Cromwell, J., Labys, W. and Terraza, M. (1994) Univariate Tests for Time Series Models. Sage Publications, Thousand Oaks, CA.

[38] Development Core Team (2013) R: A Language and Environment for Statistical Computing. R Foundation for Statistical Computing, Vienna, Austria. http://www.R-project.org

[39] Circular Consar 15-19, Diario Oficial de la Federación (9/07/2007) Reglas Generales que establecen el régimen de inversión al que deberán sujetarse las sociedades de inversión especializadas de fondos para el retiro. Ciudad de México, México.

[40] Constitución Política de los Estados Unidos Mexicanos, Diario Oficial de la Federación (05/02/1917 Tomo V, 4ª Época, N 30$)$ (24/02/2017 última reforma). Ciudad de México, México. 